\title{
ENERGY SYSTEM EMISSIONS AND MATERIEL REQUIREMENTS
}




\section{DISCLAIMER}

This report was prepared as an account of work sponsored by an agency of the United States Government. Neither the United States Government nor any agency Thereof, nor any of their employees, makes any warranty, express or implied, or assumes any legal liability or responsibility for the accuracy, completeness, or usefulness of any information, apparatus, product, or process disclosed, or represents that its use would not infringe privately owned rights. Reference herein to any specific commercial product, process, or service by trade name, trademark, manufacturer, or otherwise does not necessarily constitute or imply its endorsement, recommendation, or favoring by the United States Government or any agency thereof. The views and opinions of authors expressed herein do not necessarily state or reflect those of the United States Government or any agency thereof. 


\section{DISCLAIMER}

Portions of this document may be illegible in electronic image products. Images are produced from the best available original document. 


\title{
ENERGY SYSTEM EMISSIONS AND MATERIEL REQUIREMENTS
}

\author{
Prepared for: \\ The Deputy Assistant Secretary for Renewable Energy \\ U.S. Department of Energy \\ Washington, D.C. 20585
}

\author{
Prepared by: \\ Meridian Corporation \\ 4300 King Street, Suite 400 \\ Alexandria, Virginia 22302
}

February, 1989 


\section{ENERGY SYSTEM EMISSIONS AND MATERIEL REQUIREMENTS}

- Executive Summary

- Study Approach and Organization

- Technologies

- Emissions

- Summary

- Data Appendix and Endnotes

The purpose of this analysis is to construct comparable measures of emissions and materiel requirements for power production technologies. The goal is to develop a consistent framework for making comparisons between technologies at each stage of the energy production process, as well as comparisons of the overall impacts of each generating technology taken in its entirety. The intended outcome is a cumulative view of emissions that focuses on quantities of emissions as a function of energy supplied. Five technologies are included in this analysis:

- a conventional coal plant with a scrubber (500 MW)

- an Atmospheric Fluidized Bed Combustion (AFBC) plant (500 MW)

- an Integrated Gasification Combined Cycle (IGCC) plant $(1000 \mathrm{MW})$

- a boiling water nuclear reactor (1000 MW)

- a central station photovoltaic plant (100 MW)

This study attempts to view all environmental impacts associated with a technology as part of one system designed to produce energy over the useful life of a technology. By relating environmental impacts at all stages of energy production to a technology's total useful output of energy, the usual segregated, single-aspect view of energy production is overcome and a basis is established for comparing technologies that have very different capital, fuel, and operating characteristics. 
To accomplish these purposes the analysis is conducted within a framework that delineates three basic aspects of energy production;

- Energy production stages -- fuel extraction, construction, operation, and decommissioning

- Environmental impacts - air, water, solid wastes, and materiel requirements

- Power production technologies -- coal, nuclear, and photovoltaics

These three aspects form a matrix of data that allows comparisons of environmental impacts across technologies at each stage of their energy production cycle. In order to maximize comparability, emissions and materiel demands are normalized over the entire operating life of each technology and related to a common measure of each technology's performance, gigawatt-bours ( $\mathrm{GWh}$ ) of electricity production.

Because this analysis attempts to take a unique, comprehensive view of emissions from power production technologies, only a limited amount of data were reasonably available. A limited number of studies that attempted a comprehensive view of specific power production technologies provided the basis for updating information and estimating the effects of newer technologies. For the most part, however, the literature on emissions from power production technologies tends to focus either on environmental effects or on power production, without relating the two. The information also tends to be very specialized. Some sources investigate only certain emissions from a technology and do not relate them to other emissions. Most ignore the effects of fuel extraction and plant construction. The task of generating original scientific data would require a major effort in examining and comparing the actual designs and operating information on equipment and procedures used in mining, construction, materiels fabrication, operation, and decommissioning, and then translating the information into emissions and energy production data for use in the analysis. This analysis is limited to examining major issues using data from available sources. As a result, gaps appear in the data and simplifying assumptions had to be used to produce comparable data. Further discussion of the sources and the treatment of the data used in the analysis is provided in the body of the report. 
Despite the limitations of the data and the analysis, the effort does provide insights into the environmental and materiel impacts of different energy technologies. In examining air emissions the results clearly portray the significant contribution of coal plant operation to $\mathrm{CO}_{2}, \mathrm{NO}_{x}$, and $\mathrm{SO}_{x}$ production. It also shows the relatively narrow range of improvements that can be expected from clean coal technologies such as AFBC and IGCC in reducing $\mathrm{CO}_{2}$ emissions. The IGCC investigation highlights IGCC's advantages in terms of sharply reducing $\mathrm{SO}_{x}, \mathrm{NO}_{x}$, and particulate emissions, but also shows limited impacts in terms of reducing $\mathrm{CO}_{2}$ emissions.

Comparing nuclear and photovoltaics to the coal technologies demonstrates the well-accepted notion that these two technologies are preferable from the standpoint of major air emissions. The results also clearly show that their contribution is not zero when all the elements of their fuel cycle are considered, and that they have emissions which are different but also potentially significant, especially if their role in energy production is expanded. No technology is completely environmentally benign.

Water emissions data, though limited, are useful for pointing out the key point of impact in the coal extraction stage - an impact that is often overlooked because of the separation between mining and energy conversion. By taking a "total" view of energy production this type of analysis helps quantify the problem in real terms as a direct side-effect of energy production and consumption.

Solid waste emission data clearly demonstrate the link between fuel-intensity and solid waste generation, as well as the broad range of solid wastes from coal preparation to radioactive by-products of uranium fission. All solid wastes present disposal problems and all represent a growing mass of materiel that will not dissipate rapidly, unlike many air emissions which become dilute or degrade into less harmful by-products over a relatively short time-frame. Not included are major by-products such as elemental sulfur from IGCC plants, because they have a value and are not emissions in the sense of being wastes.

In addition to direct emissions, materiel requirements of power production technologies are examined, since they can have direct or indirect environmental effects. In the case of land requirements, impacts occur at entirely different stages of energy 
production. For fuel-intensive technologies, land use is concentrated in the fuel extraction stage. For a materiels-intensive technology like photovoltaics, the major land impacts occur at the plant site. Coal facilities show a low demand for construction materiels relative to output, but have high demands for water and significant land requirements during operation and fuel extraction, respectively. Nuclear shows comparatively lower demand for concrete, steel and land, but substantial water requirements.

Photovoltaics, recognized as a highly materiels-intensive technology, does have greater materiel requirements than the conventional technologies per output, but the difference is not as great when all the aspects of energy production are considered and the investigation is expanded beyond PV's one-time construction impacts. PV land requirements, as an example, are comparable to coal strip mining. However, because of its limitations the analysis does not address the duration or quality of these impacts, which is especially important in examining materiel requirements. The land used in coal and uranium mining can be reclaimed for other uses fairly quickly. The land which PV, coal, and nuclear require for the plant site is closed to alternative uses until the plant is decommissioned and removed. At the other extreme, nuclear waste storage areas, which were not examined for lack of representative data, will require isolation for thousands of years, representing a basically permanent removal of land from other uses.

Similarly, the implications of water demand are more complex than this limited analysis implies. In the water-scarce American West, water rights and use are very important, but are less so in the Eastern U.S. Thus a conventional coal or nuclear plant's high water demand could be a major issue in one region of the country, but less so in another.

This analysis does not provide a basis for recommending one technology over another. Rather, it provides a useful comparison of the environmental aspects of these technologies, which is only one aspect that should be considered in their deployment. Without information on costs, the suitability of a technology to particular sites and energy demand situations, and localized environmental impacts associated with particular projects, it is impossible to say one technology is preferable to another. Instead the analysis points out the wide variety and extent of impacts that should be considered and their relation to energy production; it 
shows just how broad the implications of energy use are, and demonstrates the favorable environmental tradeoffs that might be made by pursuing a mix of generating technologies, each chosen to maximize benefits while limiting negative side effects.

\section{Study Approach and Organization}

By investigating the impact of each stage of the energy production process, the analysis attempts to normalize differences between representative materiel-and fuel-intensive technologies in order to provide a fair basis for comparison. When emissions and materiel demands are normalized in terms of each facility's useful power output, the association between electricity production, emissions and materiel demands for each technology becomes clearer.

The analysis constructs a comparative structure for assessing different power production technologies by examining each technology within a common framework. The first aspect of the framework is a delineation of all the environmental points of interest associated with power production systems, from extraction of fuel, to raw materiel production for plant manufacture, to plant operation, to decommissioning. Within each of these stages of energy production the analysis attempts to catalog impacts on air, water, solid wastes, and materiel requirements, noting the type and magnitude of emissions or materiel demand affecting each category of environmental impact at each stage of the energy production process. This matrix of energy production stages and emission/materiel data is produced for each technology, so that each power production technology can be compared at each stage of energy production and in terms of each type of emission or materiel demand.

Emissions are usually expressed in terms of quantities over time, which in turn relate to levels of concentration in the atmosphere. This approach is an offshoot of health-based standards, such as the National Ambient Air Quality Standards (NAAQS), which establish the parameters of a healthy environment and are then used to derive emission standards which will maintain that status. This approach is well-suited to the goals of environmental protection, but it is less useful for cross-comparing the negative and positive impacts of technologies. Pounds per hour or pounds per million Btu of input only indirectly show the impact of the product society actually consumes - watt-hours of electricity. This 
analysis attempts to make the tradeoffs between emissions and energy output clearer by construing emissions as a function of useful power output, and placing the information side by side for each technology.

Similarly, this study assesses materiel requirements in terms of the raw materiels used to fuel, build, and operate a technology as a function of useful power output rather than the usual capital cost approach. In this way the energy we use as a society can be valued in terms of the demand for raw materiels different energy technologies require, and in terms of the associated environmental impacts of using these materiels.

This study also breaks with more traditional environmental analyses in that it attempts to view all environmental impacts associated with a technology as part of one system designed to produce energy over the useful life of a technology. Consequently, the emissions and resource impacts of coal mining, coal transportation, and coal plant construction are included with the usual measurements of the environmental impacts of coal plant operations. Thus photovoltaics, which has practically no emissions during operation, but requires large one-time inputs of raw materiels, can be compared with a coal plant, which requires constant inputs of fuel and chemicals, and produces its most significant emissions during operation.

The particular power production technologies chosen for comparison were selected on the basis of providing highly contrasting impacts and operating characteristics to illustrate the range of technological considerations involved. The conventional coal plant provides a baseline for comparison; it is an established technology with well-known pros and cons that provide a benchmark for alternatives.

The Atmospheric Fluidized Bed Combustion (AFBC) plant represents an innovative alternative to conventional coal combustion and scrubbers. ${ }^{1}$ The Integrated Gasification Combined Cycle (IGCC) plant represents an emerging advanced technology which offers significant improvements in coal combustion. ${ }^{2}$ 
Nuclear reactors are a large-scale alternative to fossil fuels and present an opportunity to illustrate the very different nature of emissions from nuclear versus fossil fuel plants. Photovoltaics represents an emerging technology that provides a fundamentally different approach to the production of electricity using a renewable fuel source and exhibiting limited emission impacts during operation.

The first section of the report focuses on the power production technologies. It describes the processes and equipment involved for each technology during fuel extraction (fuel mining, transportation, preparation, etc.), construction, and operation. An examination of decommissioning was not attempted for lack of data, although it should be considered as part of the consequences of energy production.

The next section addresses the major emissions and materiel inputs used during each stage of the energy production process for each technology: 1) air emissions, 2) water emissions, 3) solid wastes, and 4) materiel requirements. Each major emission and resource is described in terms of its ecological significance. Within each category of impacts, the emission/resource profile of the various technologies are presented together with comparisons and discussions of each technology's characteristics.

By necessity the comparisons presented are generalizations. Each energy facility is to some extent unique. For example, the amount of steel and concrete used in a PV facility will vary with site conditions and the type of equipment used. Coal mining impacts depend on the extent and depth of deposits, site conditions, and mining methods. Combustion emissions from coal are impacted by both generating equipment and by coal chemistry, which varies from mine to mine. Some issues, such as the impact of iron ore mining associated with the steel used in plant construction, were simply not addressed for lack of resources.

Energy Production Stages and Technologies

Fuel Extraction

Coal Fuel Extraction - Emissions associated with fuel extraction and transportation for the coal technologies were scaled to the fuel demands of each coal technology by dividing the annual fuel demand of the power plant by the capacity of the assumed fuel 
extraction, processing and transportation facilities. This demand/output ratio was multiplied by the emissions from each fuel supply facility to derive the share of emissions from the facility attributable to the final generating plant. It was assumed that the coal supplied to each technology was mined and transported under the same conditions, so variations in emissions from fuel extraction are mainly a function of each plant's relative efficiency in burning coal. However, the emissions data for the AFBC and IGCC plant for $\mathrm{SO}_{\mathrm{x}}$ and NO $\mathrm{x}$ were based on Illinois number $4 \mathrm{coal}$, which is the design basis for these technologies and has a somewhat higher sulfur content.

The fuel extraction stage for coal includes the impacts of mining, processing and transporting fuel to the site where it will be converted to energy. It is assumed that the coal will be mined at an eastern bituminous coal surface mine which produces 2.5 million tons of coal annually from a 6 -foot seam. The coal is assumed to be $52 \%$ fixed carbon, $34 \%$ volatile matter, $9 \%$ ash, $3 \%$ moisture, and $2 \%$ sulfur. ${ }^{3}$ About 365 acres of land are affected by the mining operation each year. The coal is transported by a unit train comprised of 105 cars with a capacity of 100 tons each. Four 3000 -hp diesel locomotives haul the train on a 1400-mile round trip 90 times per year. ${ }^{4}$ A mine-mouth plant at an underground coal mine would have different magnitudes and types of impacts, but this example is more useful as an illustration of the range of possible impacts.

Nuclear Fuel Extraction - The nuclear calculations were made in the same general manner as the coal calculations, with fuel demand at the power plant traced back through fuel fabrication, enrichment, processing, and mining in order to allocate the emissions from each stage of fuel manufacture in proportion to each stage's contribution to final power production. An additional increment to emissions was added to the source values based on each fuel processing facility's electricity demand.

The impacts of electricity and fuel use were examined in order to capture some of the significant impacts of secondary energy use involved in power production, especially in the nuclear fuel cycle. A coefficient for $\mathrm{CO}_{2}$ emissions as a function of electricity production in the entire U.S. was calculated and then applied to the electricity demand of the nuclear plant. In this way electricity is treated as a generic commodity for all the technologies and the issue of allocating hydropower or other sources of power with low 
emissions is avoided. $5,6,7$ The approach used produces a national average of $\mathrm{CO}_{2}$ emissions associated with the electricity used in the energy production cycle for the technologies examined. Fuel $\mathrm{CO}_{2}$ coefficients for gas, coal and oil were also applied to the fossil fuels used at the plant and in the resource extraction stage. The other technologies were assessed in a similar fashion, where energy use data were available, but the increment to emissions was negligible.

The fuel extraction stage for the nuclear plant includes uranium mining, conversion, enrichment, and fabrication. The mine supplies 1060 tons of "yellow cake" $\left(75 \% \mathrm{U}_{3} \mathrm{O}_{8}\right)$ per year from roughly 530,000 tons of raw ore $\left(0.2 \% \mathrm{U}_{3} \mathrm{O}_{8}\right)^{8}$

The yellow cake is then converted to uranium hexafluoride at a conversion facility. The plant produces roughly 5500 tons of uranium hexafluoride annually from 7340 tons of yellow cake using either the dry hydrofluor or wet solvent exchange process, with appropriate environmental controls. The plant uses approximately $46,000 \mathrm{MWh}$ of electricity for processing.

Once the yellow cake is converted to uranium hexafluoride it is enriched to $4 \% \mathrm{U}_{235}$ for use as reactor fuel. Using the gaseous diffusion process, the plant produces approximately 12,000 tons of enriched uranium per year. The process is very energy intensive, requiring $26,000 \mathrm{MWh}$ of electricity. ${ }^{10}$

Finally the fuel is fabricated into fuel pellets, assemblies, and rods at a fuel fabrication plant. The fuel fabrication plant produces roughly 980 tons of fuel per year. ${ }^{11}$

Photovoltaics Fuel Extraction - Photovoltaics has no direct fuel extraction impacts.

Construction

The construction phase includes the indirect impacts of the technologies in terms of their demand for raw materiels and the emissions associated with manufacturing the raw materiel inputs. Steel and concrete are the major materiel inputs examined and the major sources of secondary emissions.

The construction stage accounts for the greatest differences between materiels-versus fuel-intensive technologies, with the 
former producing the highest environmental impacts at this stage. The estimates in this analysis focus exclusively on emissions from final manufacture of major materiels used in construction. Highly variable impacts such as fugitive dust emissions or exhaust from construction equipment were not evaluated for lack of typical data.

Emissions and materiel inputs used or produced in the course of construction were taken from source documents for the conventional coal, nuclear and photovoltaics plants. This does not represent a comprehensive review of all emissions. There are secondary impacts associated with the mining of raw materiels like iron ore, bauxite, etc., which are used to make the steel and other inputs to construction, but these types of impacts were not calculated for any of the technologies for lack of valid and comparable data. Emissions associated with materiels manufacture were derived by multiplying coefficients of emissions per pound of materiel times the gross quantity of materiel used by each technology. ${ }^{12}$

Both the materiel inputs and their associated emissions were divided by the annual output of the technology times the operational life of the technology to derive materiel inputs and emissions per unit of output over plant life.

Raw materiel requirements for all the technologies vary widely depending on site requirements and design specifications. The photovoltaic and nuclear raw materiel requirements were both based on specific designs. ${ }^{13,14}$ The photovoltaic plant is a conceptual design of a theoretical central station using photovoltaic materiels with efficiencies and operating characteristics that have not yet been proven. Both the nuclear and photovoltaic designs are taken as representative plants, but there has been no thorough investigation as to whether the materiels used in their designs is typical. The estimates of resource use in a coal plant are generalized estimates of what a typical plant would require.

Analyses of power plant capital requirements generally focus on dollar values rather than tonnages of raw physical inputs, and where materiels are reported they are generally given in terms of the items purchased, such as linear feet of cable or cubic yards of concrete. However, coefficients for emissions for these materiels are generally reported as a function of tons of output. Thus there are inconsistencies in the basic measurements of the materiels, 
which required that the concrete estimates be converted from cubic yards by assuming all concrete used had a mass density of 127 pounds per cubic foot. ${ }^{16}$ Cables were assumed to be aluminum, with a weight of 1 pound per linear foot. Other materiels were provided in tons as cited in the source materials.

In the case of the IGCC plant and the AFBC plant, direct estimates of materiel requirements were unavailable. Therefore the values were derived by adjusting the materiels used in a conventional plant by the proportionate capacity associated with the AFBC and IGCC plant. ${ }^{17}$ It is acknowledged that this simple assumption ignores the significant technology differences and the effects of differing economies of scale between technologies.

Emissions factors for aluminum, glass, steel and concrete were available in the source documents, and so only these materiels were used to calculate the incremental addition to emissions caused by the manufacture of raw materiels used in plant construction. ${ }^{18}$ These are the predominant raw materiels used in plant construction, so a majority of the secondary emissions are captured in the analysis. The $\mathrm{CO}_{2}$ emission factor for these four materiels was not available, but a factor was derived for steel by examining fuel demand as a function of industry output, and then multiplying the resultant estimate of fuel use per ton of output times a $\mathrm{CO}_{2}$ emission coefficient to derive an estimate of $\mathrm{CO}_{2}$ per ton of output. This estimate was then used to calculate the $\mathrm{CO}_{2}$ emissions associated with steel demands. Electricity as an energy input to steel was converted to $\mathrm{CO}_{2}$ inputs by calculating the fuel mix for electricity in 1987, multiplying the quantities by their respective coefficients, and then allocating the gross $\mathrm{CO}_{2}$ emissions over the total number of gigawatt-hours produced in $1987^{19,20,21}$

The $\mathrm{CO}_{2}$ coefficient for steel is based on reliable data from a recent, comprehensive data base. ${ }^{22}$ The coefficient for concrete is based on a study that examined concrete's role in worldwide $\mathrm{CO}_{2}$ emissions. ${ }^{23}$ The $\mathrm{CO}_{2}$ coefficients for the various fuels are based on estimates produced for global studies of $\mathrm{CO}_{2}$ emissions. ${ }^{24}$

Emissions from PV cell manufacture were not examined in detail, nor were data included in the main data matrices simply because there is little overlap between the significant emissions from the manufacture of PV materiels and the other technologies, so there is no basis for comparison. However, a table showing some of the 
annual emissions from a PV manufacturing plant are included in separate tables at the end of the data appendix. ${ }^{25}$

Operation

In the case of the conventional coal plant and the nuclear plant, the values for emissions and materiel inputs associated with operations were taken from the source documents. The annual value was then divided by the annual GWh of output for each technology to derive emissions per unit of output. The values for the IGCC and AFBC plants were assumed to be similar, in terms of the rate of emissions, to the conventional plant and thus were only adjusted for the increased efficiency and power output per ton of coal input gained from each technology (if any). The only values that were examined independently were $\mathrm{SO}_{x}, \mathrm{NO}_{x_{1}}$. particulates, scrubber sludge, ash, and water demand. These factors were adjusted so that they agree with comparative assessments provided in the source documents. The impacts of maintenance and repair activities were not assessed for any of the technologies.

For photovoltaies the major impact during operation is water used in array cleaning. ${ }^{26}$ This value was included because it was built into the design used to represent photovoltaics. However, recent photovoltaic designs either eliminate or drastically reduce array washing requirements, simply because it has been found to be unnecessary and/or uneconomic. Therefore this estimate of water requirements should be taken as a value at the high end of the range of estimates.

Coal-Impacts at the operation stage are measured in terms of emissions produced while the plants are actively generating energy. The conventional coal plant in the assessment is assumed to be a $500 \mathrm{MW}$ facility producing $3500 \mathrm{GWh}$ of electricity annually. It represents a new plant built to meet or exceed existing environmental standards, and to maximize performance. The plant lifetime is assumed to be 30 years. About 1.9 million tons of eastern bituminous coal is consumed annually. The coal is processed to remove unusable portions of the coal and prepare it for feed to the boiler, which results in significant coal wastes, which are included in plant operations. Particulates are controlled by an electrostatic precipitator $A$ wet lime/limestone scrubber is used to control $\mathrm{SO}_{x}$ emissions. 27 
The AFBC plant controls sulfur in the combustion chamber, and thus the flue gases only have to be treated to remove particulates. In addition, the fluid motion of the solids in the combustion bed improves combustion efficiency and allows combustion to take place at lower temperatures, which reduces the formation of $\mathrm{NO}_{\mathrm{x}}$. The AFBC plant examined is rated at $500 \mathrm{MW}$ with annual energy production of $3500 \mathrm{GWh}$. Its useful life is 30 years. Nearly 2 million tons of Illinois coal is required to fuel the plant annually. Particulates are controlled by either an electrostatic precipitator or a baghouse. $^{28}$

Major advantages of IGCC technology include eliminating the need for flue gas cleanup, the production of solid wastes which are environmentally benign and actually have by-product value, less demanding requirements for coal quality, and enhanced $\mathrm{SO}_{x}$ and NOx removal. The space required for an IGCC plant is comparable to the land requirements for a conventional plant with scrubber, so the IGCC system has little relative impact on land requirements. IGCC technology also promises to reduce power plant water demand by $40-50 \%$. ${ }^{29}$ The IGCC plant is rated at 945 MW and produces roughly $6700 \mathrm{GWh}$ annually. The assumed heat rate for the plant is $8,920 \mathrm{Btu} / \mathrm{kWh}$. Its useful life is 30 years. The plant consumes roughly 3 million tons of coal annually. ${ }^{30}$

Nuclear-The nuclear plant is a boiling water reactor design rated at $1000 \mathrm{MW}$, producing $6130 \mathrm{GWh}$ annually. It utilizes natural draft cooling towers, which are the main source of make-up water requirements. The plant requires 34 tons of uranium fuel annually. Its useful life is 30 years. ${ }^{31}$ The advantages of nuclear include very small fuel requirements and very limited fossil fuel emissions, although nuclear plants do produce a range of other emissions that have significant environmental implications.

Photovoltaics-The PV plant is assumed to be a $100 \mathrm{MW}$ facility located at Barstow, California. Photovoltaics' main advantage is its freedom from fuel and related emissions, and the option of deploying the technology in modular increments closely matched to utility demand requirements. The representative plant consists of ground-mounted arrays of flat-plate thin-film silicon modules with an assumed 15\% efficiency, based on research expectations. These are specifications for a conceptual commercial photovoltaic plant, once competitive cells and modules are developed. Total energy production is $209 \mathrm{GWh}$ annually over a 30-year life span. ${ }^{32}$ 
It would provide peaking power to the utility system, compared to the baseload generation available from the other technologies.

The major air emissions examined are carbon dioxide (Figure 1), nitrogen oxides (Figure 2), sulfur oxides (Figure 3), and particulates (Figure 4).

Coal--For the coal technologies, most air emissions occur during operations, barring significant particulate emissions at the fuel extraction stage. $\mathrm{CO}_{2}$ emissions per ton of coal combusted are assumed to be basically similar for each technology, but the gross emissions are spread over a higher GWh output per ton of coal for the IGCC plant. This is an important point because efficiency in generation can be as effective at reducing emissions as efficiency in end-use, especially for pollutants such as $\mathrm{CO}_{2}$ which are less amenable to technological control measures.

Among the various coal technologies, the conventional plant discharges the highest emissions, followed closely by the AFBC plant, which does offer significant advantages in reducing $\mathrm{NO}_{\mathrm{x}}$. AFBC plants use varying ratios of lime within the bed of the boiler which acts as a sorbent for sulfur. NOx production within an AFBC boiler is minimized by using lower operating temperatures. ${ }^{33}$ An IGCC plant minimizes $\mathrm{SO}_{x}$ emissions by converting the coal to gas and scrubbing the gas before it is combusted. The IGCC process also significantly reduces $\mathrm{NO}_{x}$ emissions. $^{34}$

To an extent, these types of emission reductions are driven by cost. The technology exists to remove or avoid the production of very high proportions of particulates, $\mathrm{SO}_{x}$, and $\mathrm{NO}_{x}$ emissions in both conventional and advanced plants, but cost is a constraining factor. The technology for removing $\mathrm{CO}_{2}$ from coal plant emissions is less feasible, technologically and economically.

Nuclear-Air emissions from the nuclear reactor should be viewed as a range, since a portion of the emissions are associated with fossil fuel combustion required to produce electrical and other inputs to uranium processing operations and the occasional use of fossil fuel boilers and generators during operation. There is also an 
input of fossil fuel to operate backup and auxiliary steam and electricity generators at the plant site during normal refueling and operations. ${ }^{35}$ The effect of these systems varies depending on plant design, the occurrence and extent of planned and unplanned outages, and normal maintenance requirements. Note that the $\mathrm{CO}_{2}$ emissions were calculated using standard fuel coefficients and a national average coefficient for electricity, as explained in the discussion of fuel extraction for the nuclear plant. Because most emissions from nuclear plants are not comparable to photovoltaics or coal, they are not included in the summary tables, but they are noted in the more detailed data provided in the appendix.

Photovoltaics-Air emissions from the photovoltaic plant are exclusively related to the construction of the plant and the emissions from the steel, concrete, and aluminum plants that manufacture the raw materiels. ${ }^{36}$ Air emissions related to PV construction are higher than the emissions related to construction for the other technologies because of the materiels-intensity of photovoltaic technology. But overall photovoltaic emissions are a very small fraction of the emissions from coal technologies and are

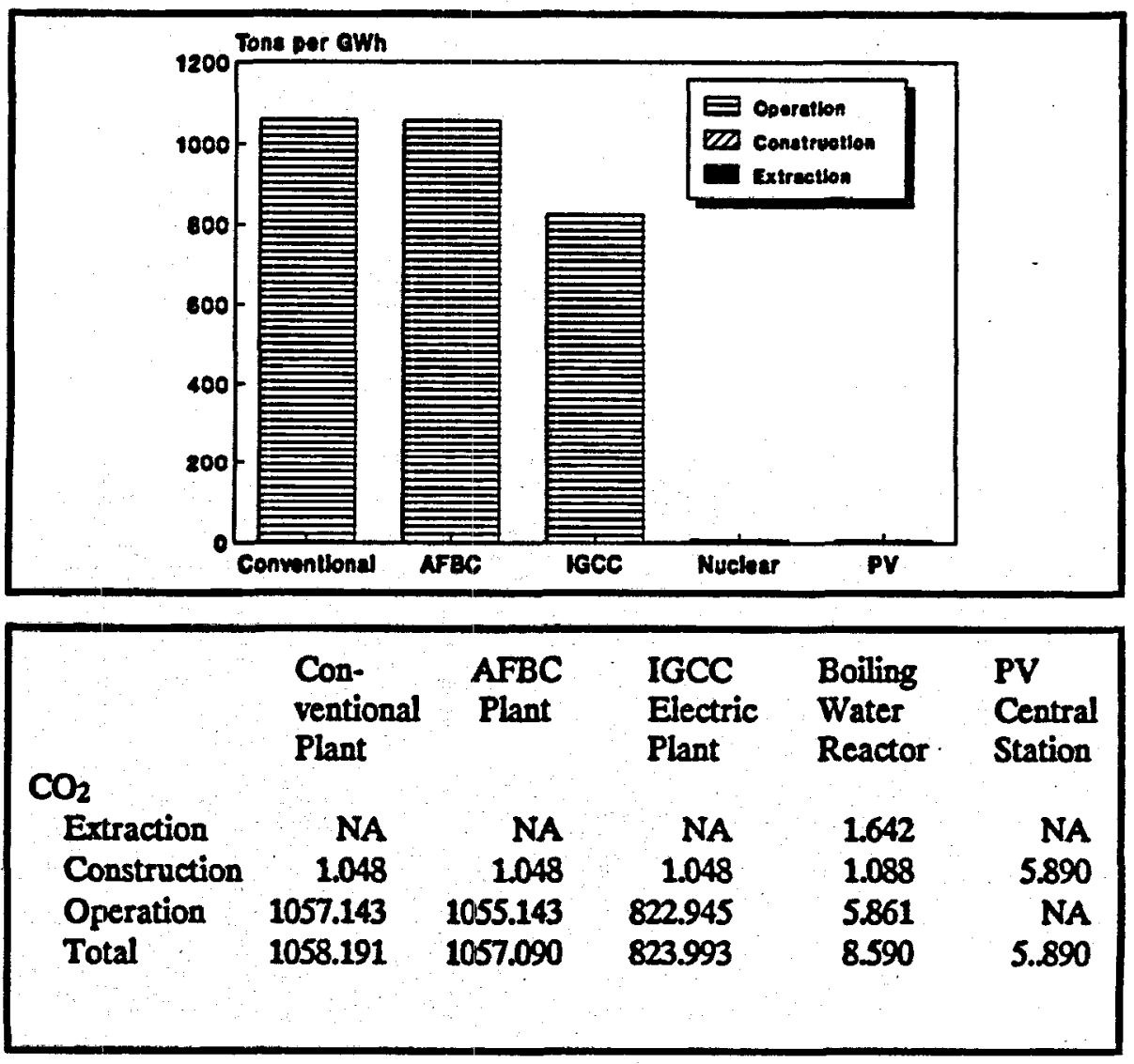

Figure 1: Carbon Dioxide Emissions 
for the most part less than or comparable to nuclear. Like nuclear, PV has emissions (associated with cell manufacture) that are unique and have no counterparts in other technologies' emissions. Possible emissions are presented in the table which follows the data appendix.

\section{Air Emission Characteristics}

Carbon dioxide $\left(\mathrm{CO}_{2}\right)$ is a nonregulated emission with no significant biological impacts, but is the most significant factor in the greenhouse/global warming effect. $\mathrm{CO}_{2}$ from fossil fuel combustion is considered by some scientists as a major environmental concern, because the gas is suspected of trapping solar heat in the lower atmosphere, resulting in a general global warming trend. In turn, this warming could adversely impact rainfall patterns, sea levels, and agriculture through its impacts on the global climate system. ${ }^{37}$

Nitrogen oxides $\left(\mathrm{NO}_{\mathrm{x}}\right.$ ) can produce respiratory illness and lung damage. They are also a key element in the photochemical effect which produces ozone. Ozone causes respiratory tract problems,

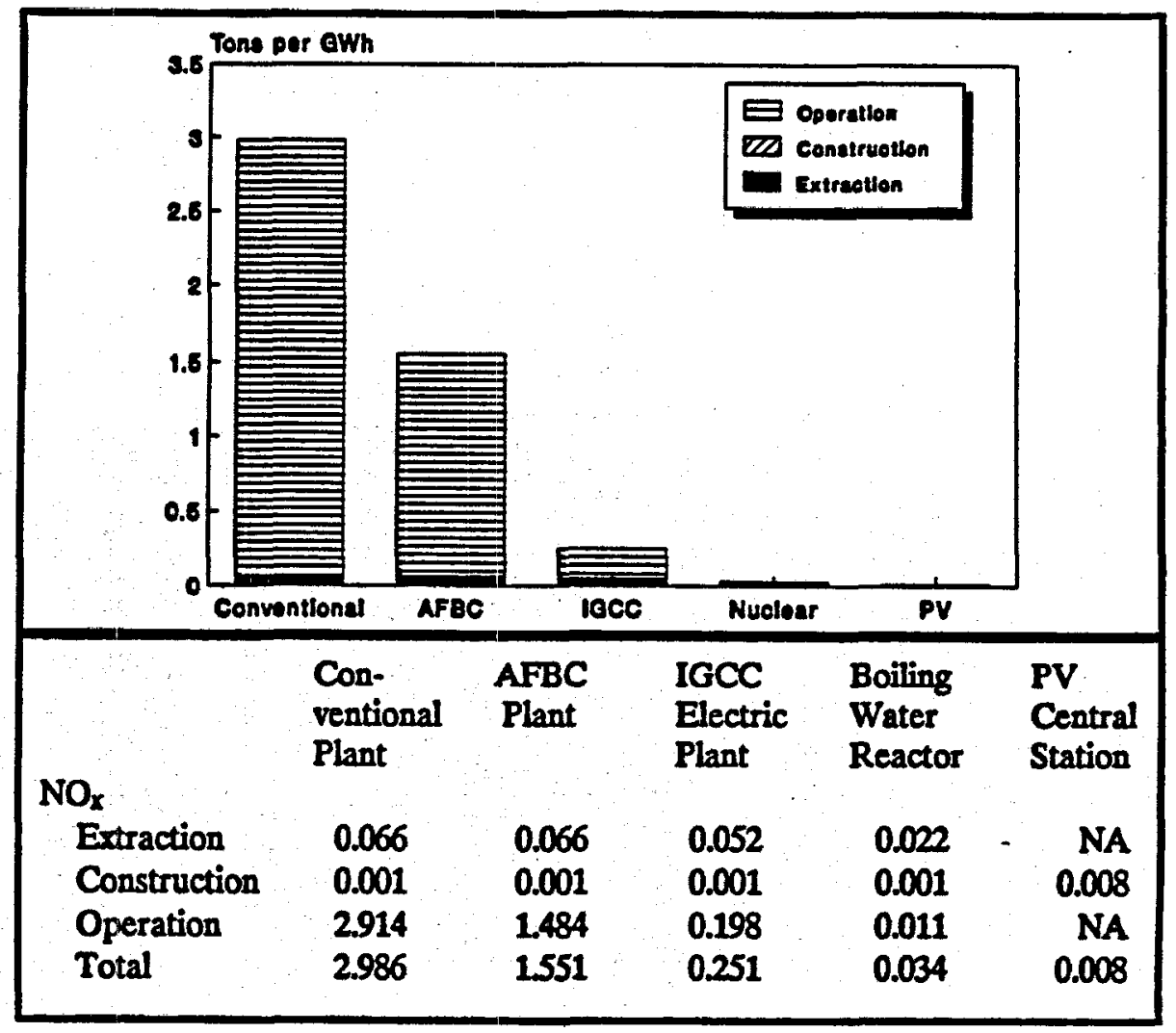

Figure 2: Nitrogen Oxide Emissions 


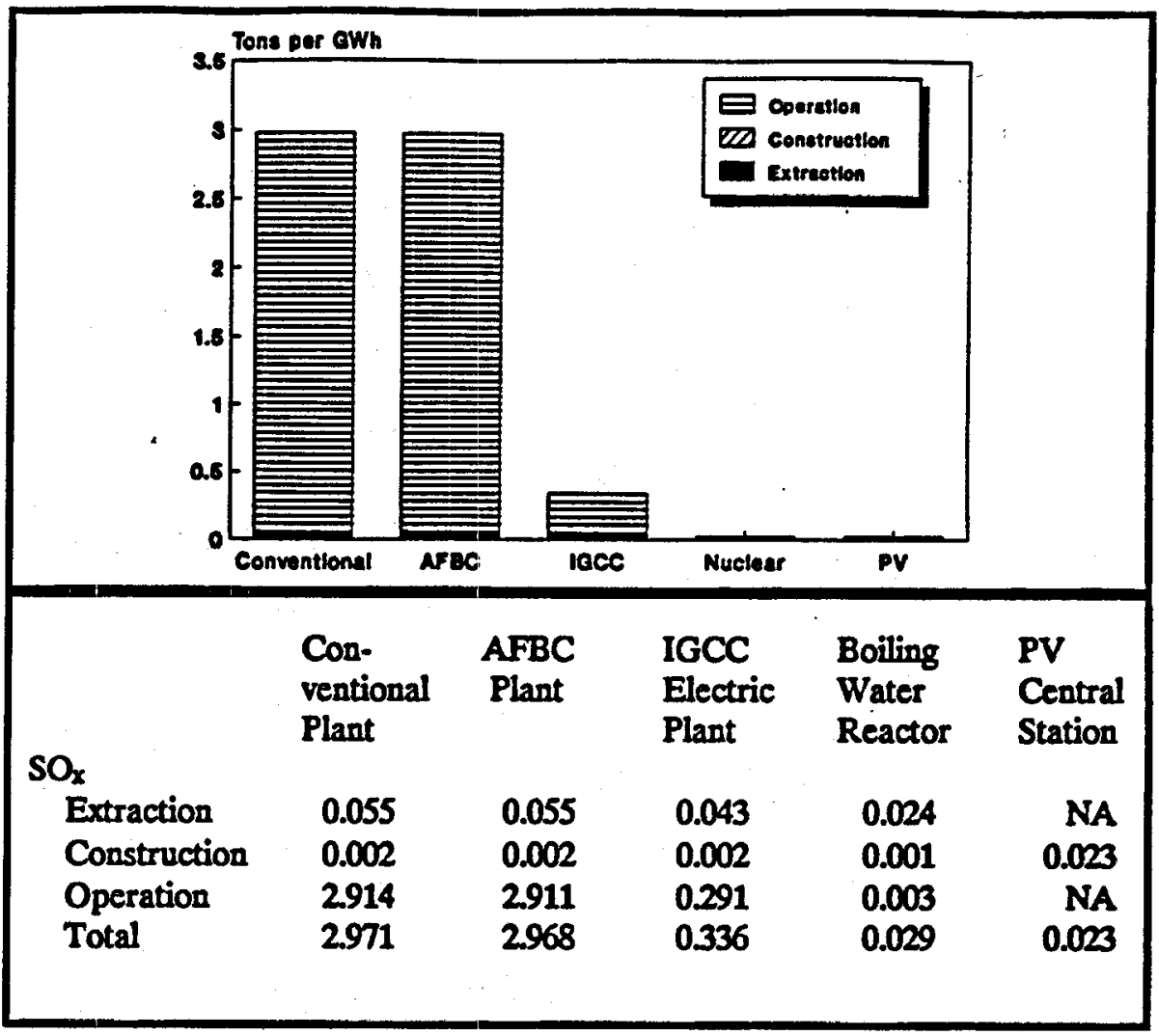

Figure 3: Sulfur Oxide Emissions

eye irritation, nasal congestion, reduced resistance to infection, and possible premature aging of lung tissue. ${ }^{38} \mathrm{NO}_{\mathrm{x}}$ is also a factor in acid rain.

Sulfur oxides $\left(\mathrm{SO}_{x}\right)$ produce respiratory tract problems and also harm lung tissues. $\mathrm{SO}_{\mathrm{x}}$ is also a precursor to acid rain, which damages aquatic habitats, forests, crops, and buildings. 39

Particulates are a concern because they can cause eye and throat irritation, bronchitis, lung damage, and impaired visibility. They are also a transport mechanism for trace metals emitted during combustion, such as lead, cadmium, zinc, and arsenic. ${ }^{40}$ Trace metals have a variety of toxic effects on humans and animals. ${ }^{41}$ More information on trace metal emissions is contained in the appendix.

In addition to the major air emissions summarized here, a range of other emissions were also investigated. The results are shown in the data appendix. Aldehyde emissions for coal were derived from published estimates for coal fuel extraction, from the exhaust from heavy equipment and train transport. Estimates for aldehyde 


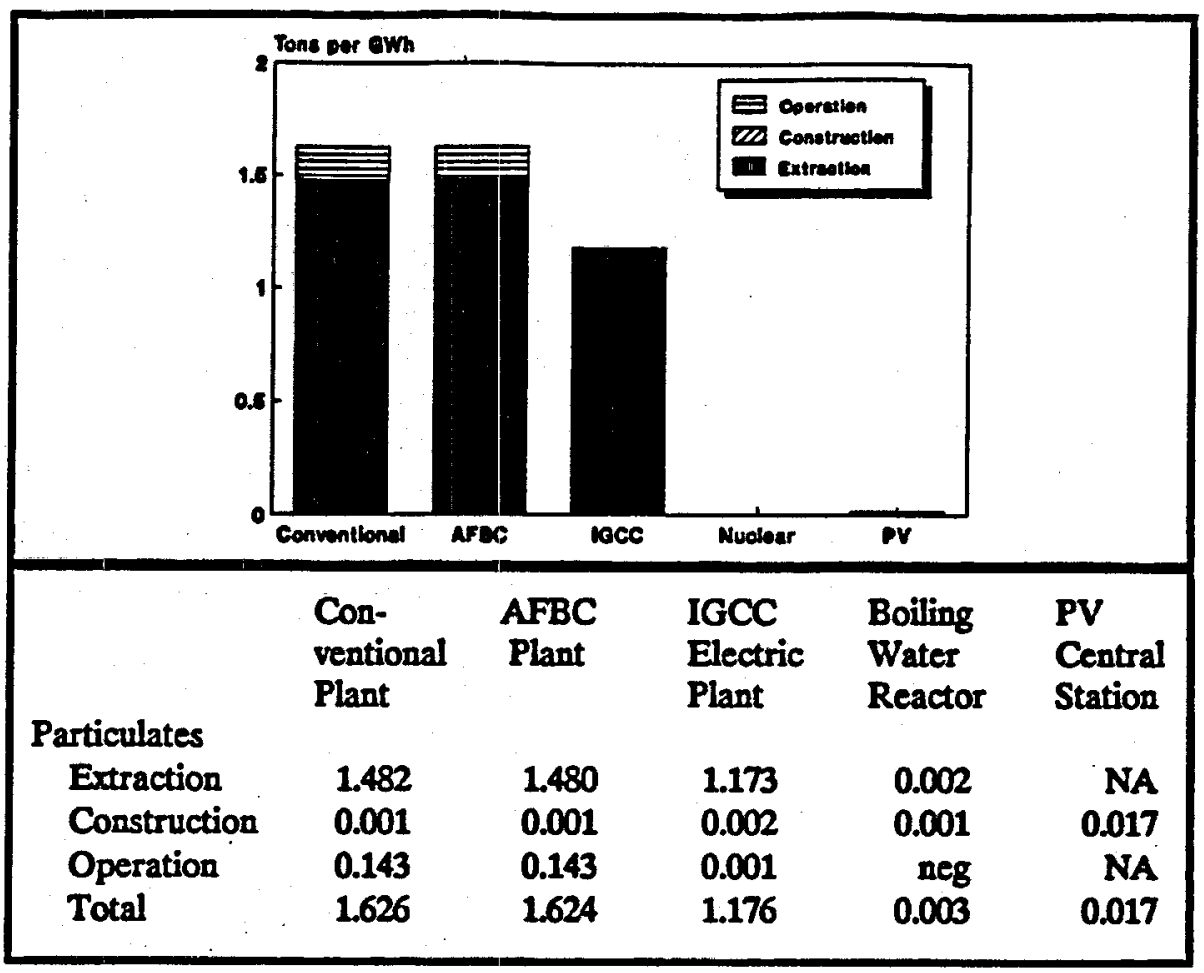

Figure 4: Particulate Emissions

emissions from coal plant operation were not available. This estimate also fails to capture aldehyde emissions from heavy equipment used in PV and coal plant construction, but the missing portions of the data are probably insignificant compared to fuel extraction, which involves the continuous use of heavy equipment to move tons of materiels. Aldehyde emission data for uranium extraction are unavailable.

Trace metals emissions are a product of coal chemistry and the ability of control equipment to reduce particulate emissions, which are the main transport mechanism for trace metals. Estimates of trace metals emissions from AFBC and IGCC plants were not available and were not estimated because of the difficulty in evaluating different combustion characteristics and particulate control technologies to derive an adequate estimate from the available data.

Radioactive air emissions from nuclear plants have no counterpart emissions for coal or PV plants, with the exception of minor amounts of uranium and associated radon that are bound up as trace elements of some coals. Different types of emissions occur at different stages of the uranium fuel cycle, so even different steps 
in the nuclear cycle are difficult to compare. All figures are derived from the data sources.

Water Emissions

The major water impacts associated with energy production are dissolved and suspended solid emissions. They are complementary measures of amounts of foreign materiel in the water.

Water emissions data are generally from the source materiels. Information on discharges for coal technologies concentrate on fuel extraction, transportation, and plant manufacture. It is impossible to estimate emissions from plant operations because surface runoff varies widely from site to site. ${ }^{42}$ Effects of runoff during plant construction are also not estimated for lack of data, and because of wide variability from site to site. Nuclear plants have a much wider variety of both radioactive and chemical emissions because of extensive emissions from extraction and processing of uranium.

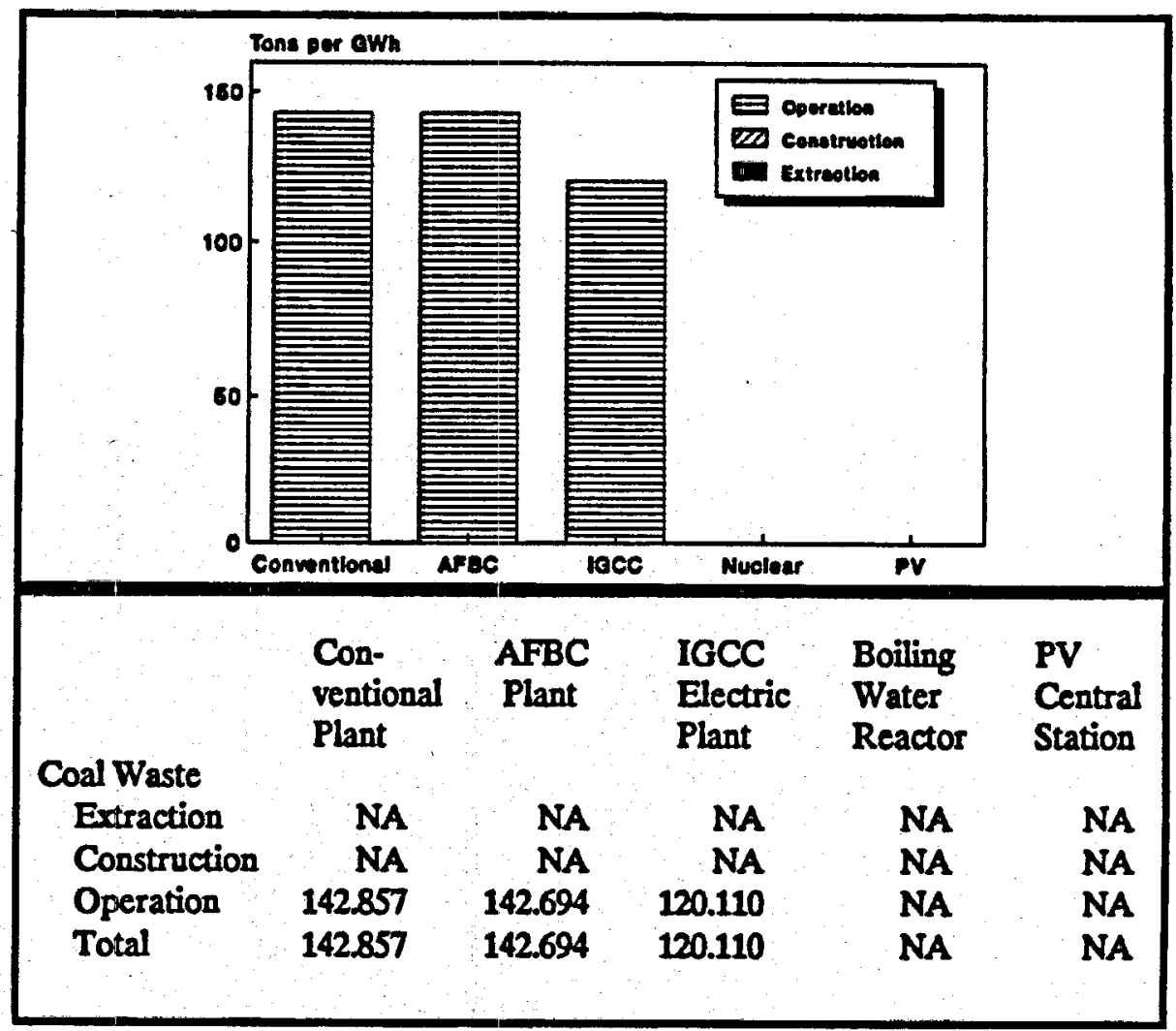

Figure 5: Coal Wastes 


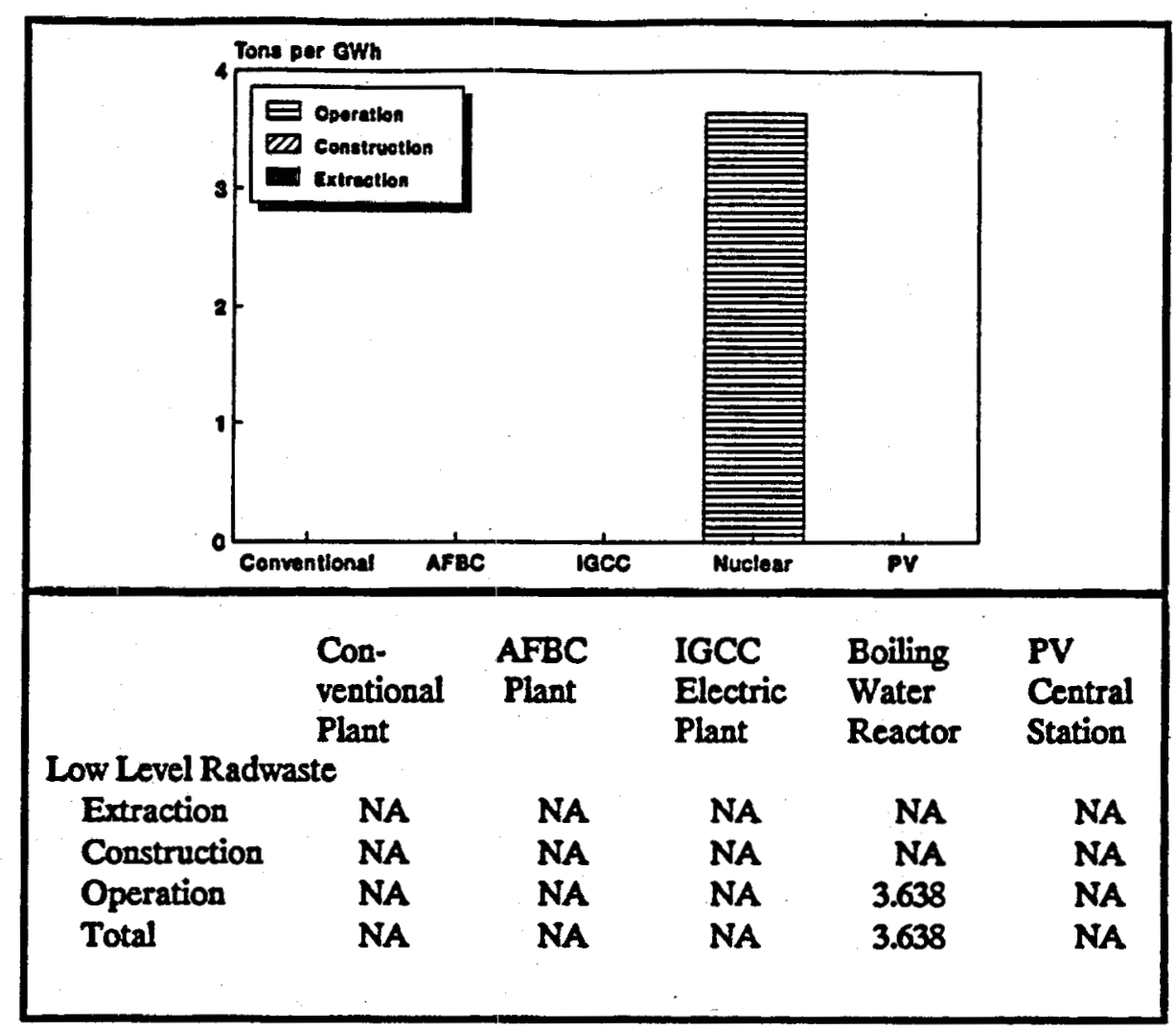

Figure 6: Low-Level Radioactive Waste

\section{Solid Waste Emissions}

Solid waste emissions are shown on a gross basis because some of the technology information lacks a breakdown of solid wastes by type, hindering comparison. Data on two major categories of solid waste from coal and nuclear technologies are shown in Figures 5 and 6, respectively. A measure of mining overburden was not available. Solid waste emissions are based on available data for conventional coal, nuclear, and PV technologies. Iron oxide, slag, pickle liquor, and part of the dust/sludge data are variable with steel manufacturing processes, depending on methods used to recycle waste products. ${ }^{43}$ Data were not available to estimate solid waste emissions from other materiels manufacturing processes besides steel. The ash figure for IGCC is based on the percentage of ash in the coal times the amount of coal used, minus the small amount emitted as particulates.

Coal-Typical waste for coal technologies would include scrubber sludge (for a conventional plant using a flue gas desulfurization system), depleted sorbent materiel from AFBC plants, fly ash, bottom ash, and waste materiel from coal preparation. IGCC 
plants also produce significant quantities of elemental sulfur, but it is sold as a by-product, and is not reported here. ${ }^{44}$ The ash and other materiels from coal plants carry varying concentrations of heavy metals and other elements found in the coal and pollution control equipment. ${ }^{45}$ In general, coal ash is not classified as hazardous, so its main environmental impact is felt in terms of demand for limited landfill space. Scrubber sludges are treated and contained onsite, and would not normally be released to the environment. ${ }^{46}$ Data were not available on overburden from coal mining, partly because it varies widely from deposit to deposit.

Nuclear-Low-level radioactive waste is an important quantity because of the difficulty in isolating and disposing of the materiels in an environmentally safe manner. Because of their high carcinogenic and teratogenic impact, and long lifetimes, radioactive wastes are fundamentally different from coal or other wastes. Overburden from uranium mining is significant both for the quantities involved and the radioactivity left in the tailings, but estimates were not included in the summary data for lack of corresponding values for coal.

Photovoltaics-Photovoltaics' only solid waste emissions are the product of raw materiel manufacturing in the construction stage.

Materiel demands are mainly of concern because of the environmental impacts associated with making the materiels. There is also the potential problem of demand for scarce or critical materiels.

Materiel information in this analysis is limited to major inputs to the technologies: land, steel, and water. Data on each are presented in Figures 7, 8, and 9, respectively. This information provides an indication of the relative size of the secondary impacts associated with each technology in terms of indirect environmental impacts caused by demand for materiels.

Coal-Coal is very materiels-intensive in terms of water demand for plant operations and land use in coal mining. The alternative coal plants are somewhat comparable in construction materiels intensity, although the IGCC technology is somewhat less reliant on water than the conventional plant. Unlike emissions, materiels are not closely correlated with capacity and output because of 


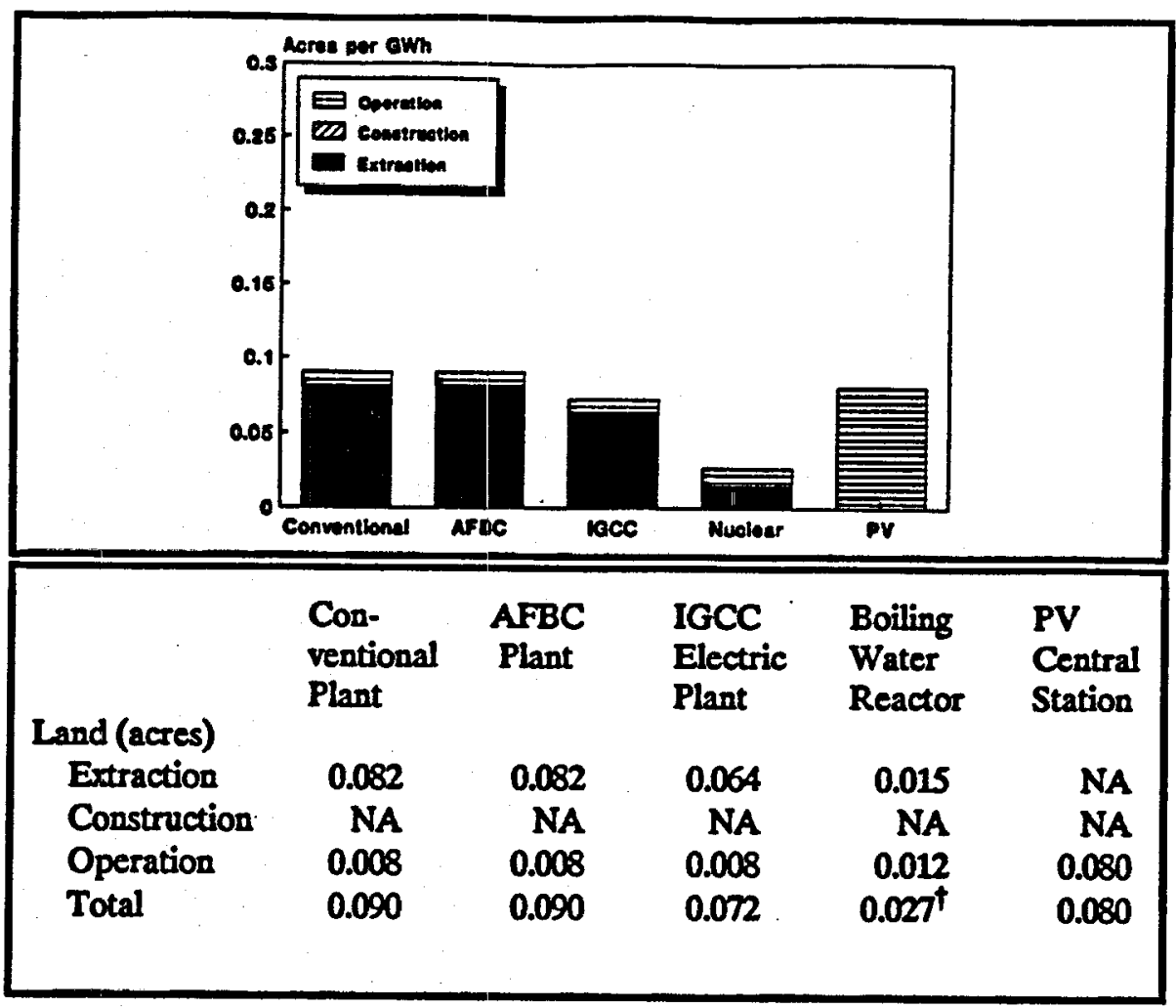

Figure 7: Land Utilization

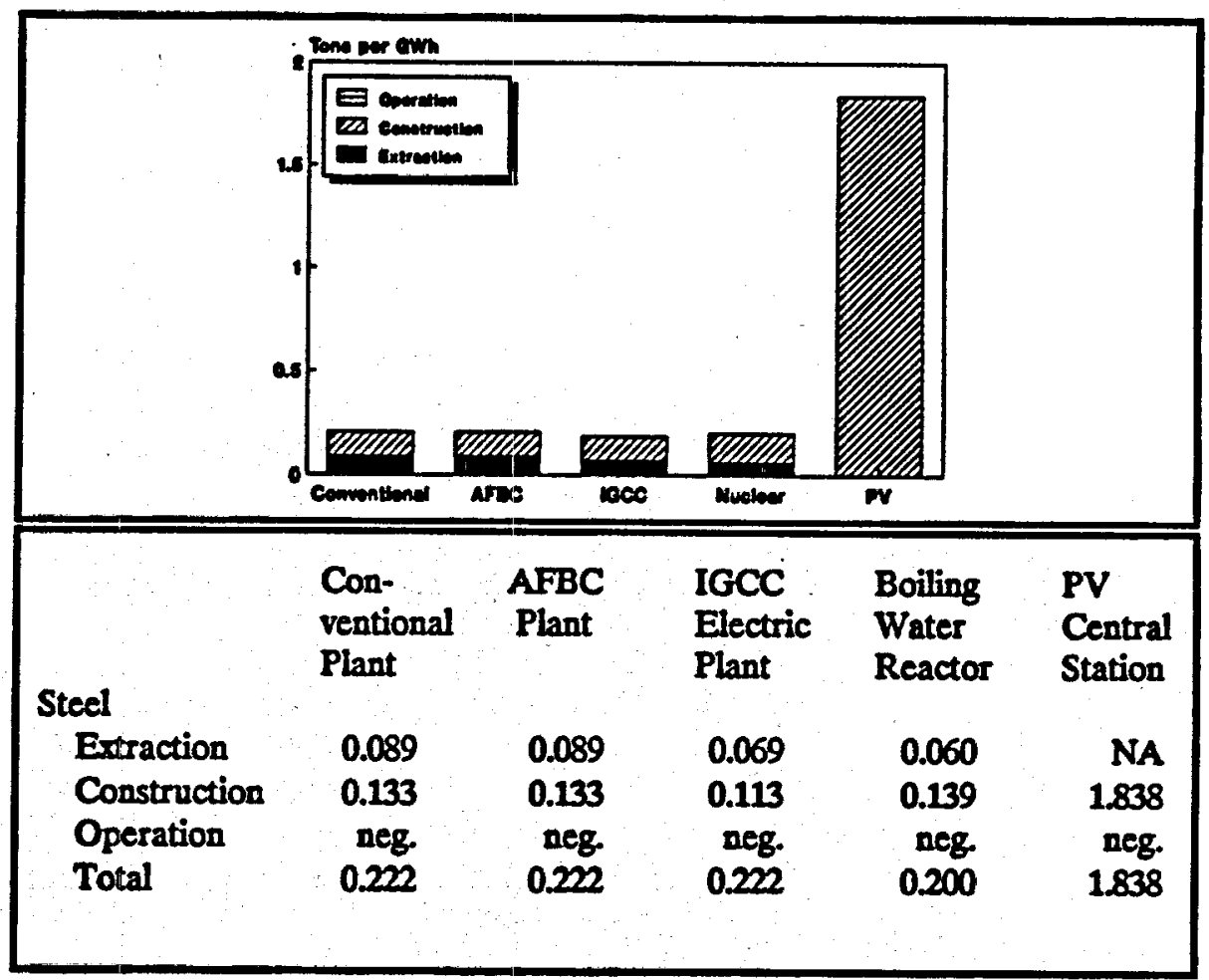

Figure 8: Steel Utilization

t Total includes mining activity at a surface uranium mine, as well as the acreage of the conversion and fuel fabrication facilities and the plant site. Land use for the enrichment facility, waste reprocessing, permanent waste storage, and plant decommissioning are not included. 


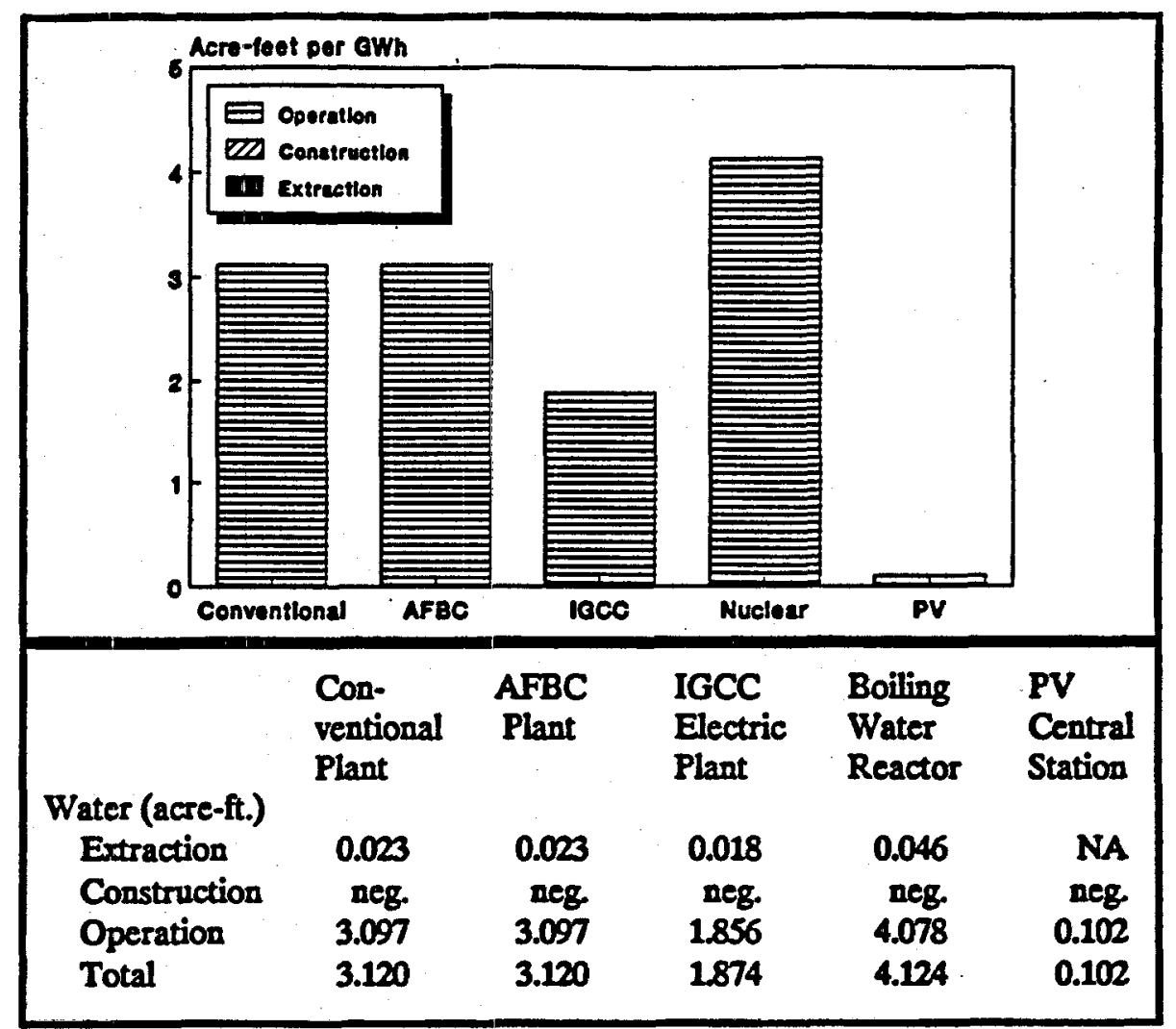

Figure 9: Water Utilization

economies of scale in building. As an example, an $800 \mathrm{MW}$ power plant will not require twice the steel and concrete of a $400 \mathrm{MW}$ power plant. ${ }^{47}$ Materiels intensity can also vary widely with design considerations and the demands of different sites. ${ }^{48}$

Nuclear -Nuclear requires large inputs of water, especially in the operations stage, but it is only moderately materiels-intensive in the construction phases. There are significant land impacts from uranium mining, but they appear to affect a smaller area than coal strip mining.

Photovoltaics--Photovoltaics is a materiels-intensive technology in the construction phases, especially for structural materiels. However, in terms of land it is comparable with coal when strip mining is considered. It compares very favorably with coal and nuclear for water use.

\section{Summary}

When compared on the basis of emissions and materiel inputs used versus power output over the life of an energy facility, the 
environmental advantages of a materiels-intensive technology like photovoltaics versus a fuel-intensive system such as a coal plant become clear. The emissions from a photovoltaic plant originate in the production of materiels--concrete, steel, glass, etc.,---that go into constructing the plant.

A photovoltaic plant's environmental impacts are proportionately larger than a coal plant's at the construction stage. However, once it is installed a photovoltaic plant's ongoing impacts are small. In comparison, a coal plant generates continual increments to emissions and places continual demands on fuel resources for every unit of output, on top of the one-time environmental impact associated with materiels used in construction of the plant. To a lesser extent, nuclear fuel requirements create the same ongoing emission problem, although a nuclear plant's emission profile is radically different from coal or $\mathrm{PV}$. These fuel-related emissions far exceed the one-time impacts of construction-related impacts in overall magnitude and in terms of emissions as a function of power output. 
$\mathrm{CO}_{2}$

\section{AIR EMISSIONS: ELECTRIC GENERATION SYSTEMS (Tons per GWh)}

$\begin{array}{lllll}\text { Con- } & \text { AFBC } & \text { IGCC } & \text { Boiling } & \text { PV } \\ \text { ventional } & \text { Plant } & \text { Electric } & \text { Water } & \begin{array}{l}\text { Central } \\ \text { Plant }\end{array} \\ & \text { Plant } & \text { Reactor } & \text { Station }\end{array}$

Fuel Extraction

Construction

Operation

- Total

$\mathrm{NO}_{x}$

Fuel Extraction

Construction

Operation

Total

$\mathrm{SO}_{\mathrm{x}}$

Fuel Extraction

Construction

Operation

Total

Particulates

Fuel Extraction

Construction

Operation

Total

Co

Fuel Extraction

Construction

Operation

Total

HC

Fuel Extraction

Construction

Operation

Total

Aldehydes

Fuel Extraction

Construction

Operation

Total
Plant

$\begin{array}{rrrrr}1.048 & 1.048 & 1.048 & 1.042 & \text { NAt } \\ 1057.143 & 1055.942 & 822.945 & 5.861 & 5.890 \\ 1058.191 & 1057.090 & 823.993 & 8.590 & \text { NA } \\ & & & & \\ 0.066 & 0.066 & 0.052 & 0.022 & \text { NA } \\ 0.001 & 0.001 & 0.001 & 0.001 & 0.008 \\ 2.914 & 1.484 & 0.198 & 0.011 & \text { NA } \\ 2.986 & 1.551 & 0.251 & 0.034 & 0.008\end{array}$

0.055
0.002

2.914

2971

0.055

0.002

2.911

2968

1.482

0.001

0.143

1.626

1.480

0.001

0.143

1.624

0.061

0.001

0.206

0.267

0.061

0.001

0.205

0.267

0.039

0.063

0.102

0.039

0.063

0.102

0.008

0.008

neg $\ddagger$

0.008

\subsection{3}

0.002

0.291

0.336

1.173

0.002

0.001

1.176

0.048

0.001

0.016

0.018

$0.030 \quad 0.001$

NA

$-\quad-\quad 0.002$

$-\quad$ NA

$\begin{array}{lll}- & 0.001 \quad 0.002\end{array}$

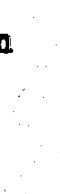

0.008

0.006
neg
0.006

$\begin{array}{rr}- & \text { NA } \\ \text { neg } & \text { NA } \\ \text { neg } & -\end{array}$

\footnotetext{
$\therefore$
} 
AIR EMISSIONS: ELECTRIC GENERATION SYSTEMS (Cont'd) (Tons per GWh)

Trace Metals

$\begin{array}{lllll}\text { Con- } & \text { AFBC } & \text { IGCC } & \text { Boiling } & \text { PV } \\ \text { ventional } & \text { Plant } & \text { Electric } & \text { Water } & \text { Central } \\ \text { Plant } & , & \text { Plant } & \text { Reactor } & \text { Station }\end{array}$

Arsenic

Fuel Extraction

Construction

Operation

Total

Cadmium

Fuel Extraction

Construction

Operation

Total

Manganese

Fuel Extraction

Construction

Operation

Total

Lead

Fuel Extraction

Construction

Operation

Total

NA
NA
0.064
0.064

NA

NA

NA

NA

NA

NA

NA

NA

0.064

NA

NA

0.001

0.001

NA
NA
0.043
0.043

NA

NA

NA

NA

NA NA

NA NA

NA NA

NA NA

Selerium

Fuel Extraction

Construction

Operation

Total

NA

0.030

0.030

Noble Gases

Fuel Extraction

Construction

Operation

Total

Tritium

Fuel Extraction

Construction

Operation

Total

C14

Fuel Extraction

Construction

Operation

Total

Radon

Fuel Extraction

Construction

Operation

NA

0.016

0.016

NA

NA

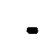

- NA

NA

NA NA NA

NA NA NA

$-\quad$ NA NA

- NA NA

-

NA

NA

NA

NA

NA

NA

NA

NA

NA

NA

NA

NA

NA

NA

NA

NA

NA

NA

NA

NA

NA

.

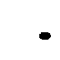

NA

NA

NA

NA

NA

NA

NA

NA

NA

NA

NA

NA

NA

NA

NA

NA

NA
NA

.

NA

NA

NA

Total

NA

NA

NA

NA

NA

NA

NA

NA

NA

NA

1843

1843

NA

NA

NA

NA

NA

NA

NA

NA NA

NA NA

$0.018 \quad$ NA

$0.018 \quad$ NA

NA NA NA

NA NA NA

NA $0.001 \quad$ NA

NA $0.001 \quad$ NA

NA $\quad 0.092 \quad$ NA

NA NA NA

NA NA NA

NA $0.092 \quad$ NA 


\section{WATER EMISSIONS: ELECTRIC GENERATION SYSTEMS}

(Tons per GWh)

Dissolved Solids

Fuel Extraction

Construction

Operation

Total

Suspended Solids

Fuel Extraction

Construction

Operation

Total

Oil/Grease

Fuel Extraction

Construction

Operation

Total

Ammonia

Fuel Extraction

Construction

Operation

Total

Sulfate

Fuel Extraction

Construction

Operation

Total

Fluorine

Fuel Extraction

Construction

Operation

Total

Nitrate

Fuel Extraction

Construction

Operation

Total

Sodium

Fuel Extraction

Construction

Operation

Total

Tritium

Fuel Extraction

Construction

Operation

Total

Conventiona

Plant

AFBC

Plant

0.278

0.278

0.27

0.278

0.005

0.005

$\begin{array}{ll}\text { neg } & \text { neg } \\ \text { neg } & \text { neg } \\ \text { neg } & \text { neg } \\ \text { neg } & \text { neg }\end{array}$

neg

NA

NA

neg

0.192

neg

0.192

NA

NA

NA

NA

NA

NA

NA

NA

NA

NA

NA

NA

NA

NA

NA

NA

0.005

0.005

0.191

neg

0.191

NA

NA

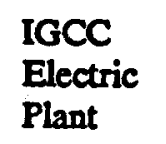

0.216

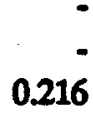

0.004

0.004

Boiling

Reactor

PV

Central

Station

NA

-

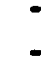

NA

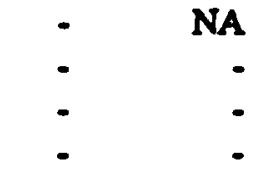

neg

neg

neg

neg

$\begin{array}{lr}\text { neg } & \text { NA } \\ \text { neg } & 0.002 \\ \text { neg } & \text { neg } \\ \text { neg } & 0.002\end{array}$

neg

NA

NA

neg

0.002

NA

NA

0.002

NA

NA

NA

NA

0.149

neg

neg

0.149

0.001

neg

0.004

0.005

NA

NA

0.005

NA

NA

0.005

neg

neg

neg

NA

NA

NA

NA

NA

NA

NA

0.004

NA

NA

NA

NA

NA

0.004

NA

NA

NA

NA

0.001

NA

NA

NA

0.002

NA

0.003

NA

NA

NA

NA

NA

NA

NA NA NA

NA $\quad 0.002 \quad$ NA

NA 0.002 NA 
SOLID WASTE EMISSIONS: ELECTRIC GENERATION SYSTEMS (Tons per GWh)

Dust/Sludge

Fuel Extraction

Construction

Operation

Total

Fly/Bottom Ash

Fuel Extraction

Construction

Operation

Total

Coal Waste

Fuel Extraction

Construction

Operation

Total

Iron Oxides

Fuel Extraction

Construction

Operation

Total

"Pickle Liquors"

Fuel Extraction

Construction

Operation

Total

Calcium Fluoride

Fuel Extraction

Construction

Operation

Total

- Mining Overburden

Fuel Extraction

Construction

Operation

Total

Low Level Radwaste

Fuel Extraction

Construction

Operation

Total

Radioactive Fiter Waste

Fuel Extraction

Construction

Operation

Total

Con-

ventional

AFBC

IGCC
Electric
Plant

Boiling
Water
Reactor

PV

Plant

Plant

neg

0.003

55.143

55.146

$$
\text { neg }
$$

0.003

$$
\text { neg }
$$

$\begin{array}{rr}0.001 & \text { NA } \\ 0.034 & 0.015 \\ \text { neg } & \text { neg } \\ 0.035 & 0.015\end{array}$

$\begin{array}{rr}\text { NA } & \begin{array}{r}\text { NA } \\ \text { neg }\end{array} \\ 35.714 & 35.674 \\ 35.714 & 35.674\end{array}$

$\begin{array}{rr}\text { NA } & \text { NA } \\ 142.857 & 142.694 \\ 142.857 & 142.694\end{array}$

NA

NA
neg
41.416
41.416

$\begin{array}{ll}\text { NA } & \text { NA } \\ \text { neg } & \text { neg } \\ \text { NA } & \text { NA } \\ \text { neg } & \text { neg }\end{array}$

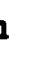




\section{MATERIEL REQUIREMENTS: ELECTRIC GENERATION SYSTEMS}

(Tons per GWh)

Steel

$\begin{array}{lllll}\text { Con- } & \text { AFBC } & \text { IGCC } & \text { Boiling } & \text { PV } \\ \text { ventional } & \text { Plant } & \begin{array}{l}\text { Electric } \\ \text { Plant }\end{array} & \begin{array}{l}\text { Water } \\ \text { Reactor }\end{array} & \begin{array}{l}\text { Central } \\ \text { Stantion }\end{array} \\ & & \text { Plant } & & \end{array}$

Fuel Extraction

$\begin{array}{rrrrr}0.089 & 0.089 & 0.069 & 0.060 & \text { NA } \\ 0.113 & 0.113 & 0.113 & 0.139 & 1.838 \\ \text { NA } & \text { NA } & \text { NA } & \text { NA } & \text { NA } \\ 0.222 & 0.222 & 0.222 & 0.200 & 1.838\end{array}$

\section{Concrete}

Fuel Extraction

Construction

Operation

Total

Aluminum

Fuel Extraction

Construction

Operation

Total

Land (acres)

Fuel Extraction

Construction

Operation

Total

Water(acre-ft)

Fuel Extraction

Construction

Operation

Total

Silicon

Fuel Extraction

Construction

Operation

Glass

Fuel Extraction

Construction

Operation

Total

0.202

$\begin{array}{rrrrr}0.876 & 0.876 & 0.875 & 0.114 & \text { NA } \\ \text { NA } & \text { NA } & \text { NA } & \text { NA } & \text { NA } \\ 0.876 & 0.876 & 0.875 & 1.816 & 1.384\end{array}$

$\begin{array}{lll}0.001 & 0.001 & 0.001\end{array}$

$0.038 \quad 0.038$

NA NA

$0.039 \quad 0.039$

0.037

NA

0.038

$0.001 \quad$ NA

- 0.019

NA NA

$\begin{array}{rrrrr}0.082 & 0.082 & 0.064 & 0.015 & \text { NA } \\ \text { NA } & \text { NA } & \text { NA } & \text { NA } & \text { NA }\end{array}$

$\begin{array}{lllll}0.008 & 0.008 & 0.008 & 0.012 & 0.080\end{array}$

$\begin{array}{llll}0.090 & 0.090 & 0.072 & 0.027+t \quad 0.080\end{array}$

$\begin{array}{lllll}0.023 & 0.023 & 0.018 & 0.046 \quad \text { NA }\end{array}$

neg neg neg neg neg

$\begin{array}{lllll}3.097 & 3.097 & 1.856 & 4.078 & 0.102\end{array}$

$\begin{array}{lllll}3.120 & 3.120 & 1.874 & 4.124 & 0.102\end{array}$

$\begin{array}{rrrrr}\text { NA } & \text { NA } & \text { NA } & \text { NA } & \text { NA } \\ \text { NA } & \text { NA } & \text { NA } & \text { NA } & \begin{array}{r}0.084 \\ \text { NA }\end{array} \\ \text { NA } & \text { NA } & \text { NA } & \text { NA } & \text { NA } \\ & \text { NA } & \text { NA } & 0.084 \\ \text { NA } & \text { NA } & \text { NA } & \text { NA } & \text { NA } \\ \text { NA } & \text { NA } & \text { NA } & \text { NA } & 1.650 \\ \text { NA } & \text { NA } & \text { NA } & \text { NA } & 1.650\end{array}$

H Total thctudes mining activity at a curface uranium mine, ss well as the acreage of the convertion and fuel tabrication fecilities and the plant site. Land use for the earichment facility, waste reprocessing permanent waste storage, and plant decommissioning are not included. 


\begin{tabular}{|c|c|c|}
\hline \multicolumn{3}{|c|}{ Atmospheric Emissions from PV Manufacturing Facilities (kg/yr) } \\
\hline Compound & Source & $\begin{array}{l}\text { Emission Rate } \\
\text { (with controls) }\end{array}$ \\
\hline Diborane & $\begin{array}{l}\text { a-Si glow discharge } \\
\text { a-Si reactive sputtering } \\
\text { a-Si CVD }\end{array}$ & $\mathbf{0}$ \\
\hline Methane & $\mathrm{Zn3} \mathrm{P}_{2}-\mathrm{MOCVD}$ & - \\
\hline Phosphine & $\mathrm{Zn} 3 \mathrm{P}_{2}$-MOCVD & 80 \\
\hline Silane & $\begin{array}{l}\text { a-Si glow discharge } \\
\text { a-Si CVD }\end{array}$ & 73 \\
\hline $\begin{array}{l}\text { Silicon } \\
\text { tetra-fluoride }\end{array}$ & a-Si glow discharge & 25 \\
\hline \multicolumn{3}{|c|}{ Solid Waste Emissions trom PVManufacturing Facilities (kg/yr) } \\
\hline Silicon Compounds & & 205 \\
\hline \multicolumn{3}{|c|}{$\begin{array}{l}\text { - Emission rates for a } 10 \mathrm{MW} \text { per year manufacturing facility. } \\
\text { ** (-) stands for an insignificant emission. }\end{array}$} \\
\hline \multicolumn{3}{|c|}{$\begin{array}{l}\text { Source: Organisation for Economic Co-Operation and Development. } \\
\text { Environmental Impacts of Renewable Energy. OECD Compass Project. } \\
\text { 1988, p. 37. }\end{array}$} \\
\hline
\end{tabular}


1. U.S. Department of Energy, Office of Fossil Energy. The Role of Repowering in America's Power Generation Future. DOE/FE-0096. December, 1987.

2. Ibid, p.7.

3. U.S. Department of Energy. Technology Characterizations: Environmental Information Handbook, DOE/EP--0028. June, 1981, p.76.

4. Ibid, p. 58.

5. U.S. Department of Energy, Energy Information Administration. Electric Power Monthly. DOE/EIA-0226 (88/06). June, 1988, p. 21.

6. Cheng, H.C., M. Steinberg, M.Beller. Effects of Energy Technology on Global CO2 Emissions. U.S. Department of Energy, Office of Energy Research. DOE/NBB-0076. April 1986, p. 52.

7. Marland G., and R.M. Rotty. CO2 Emissions From Fossil Fuels: $A$ Procedure for Estimation and Results for 1950-1981. TN: Oak Ridge Associated Universities Incorporated. DOE/NBB-0036. June, 1983, p. 13.

8. U.S. Department of Energy. Technology Characterizations: Environmental Information Handbook, DOE/EP-0028. June, 1981, p. 1.

9. Ibid, p. 4 .

10. Ibid, p. 6.

11. Ibid, p. 10.

12. U.S. Department of Energy, San Francisco Operations Office. Final Programmatic Environmental Assessment of the U.S. Department of Energy's Photovoltaic Power Program. August 1980, pp. 5-72.

13. U.S. Department of Energy. Technology Characterizations: Environmental Information Handbook, DOE/EP-0028. June, 1981, p.16. 
14. Electric Power Research Institute. Integrated Photovoltaic Central Station Conceptual Designs. Black and Veatch Engineers Architects for Electric Power Research Institute, EPRI AP-3264, June 1984, pp. g1-g19.

15. U.S. Department of Energy, Energy Information Administration. Determinants of Capital Costs for Coal-Fired Power Plants. October 1985, p. 32.

16. Marks, Mechanical Engineer's Handbook, 5th Edition, p. 671

17. U.S. Department of Energy. Technology Characterizations: Environmental Information Handbook, DOE/EP-0028. June, 1981, p.72.

18. U.S. Department of Energy, San Francisco Operations Office. Final Programmatic Environmental Assessment of the U.S. Department of Energy's Photovoltaic Power Program. August 1980, pp. 5-72 to 5-76.

19. U.S. Department of Energy, Energy Information Administration. Electric Power Monthly. DOE/EIA-0226 (88/06). June, 1988, p. 21.

20. Cheng, H.C., M. Steinberg, and M.Beller. Effects of Energy Technology on Global $\mathrm{CO}_{2}$ Emissions. U.S. Department of Energy, Office of Energy Research. DOE/NBB-0076. April, 1986 p. 52.

21. Marland G., and R.M. Rotty. CO2 Emissions From Fossil Fuels: $A$ Procedure for Estimation and Results for 1950-1981. TN: Oak Ridge Associated Universities Incorporated. DOE/NBB-0036. June 1983, p. 13.

22. "Industrial Sector Energy Analysis: The Steel Industry." Gas Energy Review. VA: American Gas Association vol. 16, no. 11, November, 1988, pp. 6-12.

23. Marland G., and R.M. Rotty. $\mathrm{CO}_{2}$ Emissions From Fossil Fuels: $A$ Procedure for Estimation and Results for 1950-1981. TN: Oak Ridge Associated Universities Incorporated. DOE/NBB-0036. June, 1983, p. 13.

24. Cheng, H.C., M. Steinberg, and M.Beller. Effects of Energy Technology on Global CO 2 Emissions. U.S. Department of Energy, Office of Energy Research. DOE/NBB-0076. April 1986, p. 52. 
25. Organisation for Economic Co-Operation and Development. Environmental Impacts of Renewable Energy. OECD Compass Project. 1988, p. 37.

26. Electric Power Research Institute. Integrated Photovoltaic Central Station Conceptual Designs. Black and Veatch Engineers Architects for Electric Power Research Institute, EPRI AP-3264, June 1984, p. 3-24.

27. U.S. Department of Energy. Technology Characterizations: Environmental Information Handbook, DOE/EP-0028. June, 1981, p. 72.

28. U.S. Department of Energy, Office of Fossil Energy. The Role of Repowering in America's Power Generation Future. DOE/FE-0096. December, 1987, p. 11, 15.

29. Spencer, Dwain F, Michael J. Gluckman, and Seymour B. Alpert. "Coal Gasification for Electric Power Generation," Science, Vol. 215, March 26, 1982.

30. U.S. Department of Energy, Office of Fossil Energy. The Role of Repowering in America's Pover Generation Future. DOE/FE-0096. December, 1987, p. 9, 15.

31. U.S. Department of Energy. Technology Characterizations: Environmental Information Handbook, DOE/EP-0028. June, 1981, p. 16.

32. Electric Power Research Institute. Integrated Photovoltaic Central Station Conceptual Designs. Black and Veatch Engineers-Architects for Electric Power Research Institute, EPRI AP-3264, June 1984.

33. U.S. Department of Energy, Office of Fossil Energy. The Role of Repowering in America's Power Generation Future. DOE/FE-0096. December, 1987, p. 11.

34. Ibid, p. 9.

35. U.S. Department of Energy. Technology Characterizations: Environmental Information Handbook, DOE/EP-0028. June, 1981, appendix p. 29. 
36. U.S. Department of Energy, San Francisco Operations Office. Final Programmatic Environmental Assessment of the U.S. Department of Energy's Photovoltaic Power Program. August 1980, p. 5-72 to 5-76.

37. Schelling, Thomas C. "Anticipating Climate Change-Implications for Welfare and Policy." Environment, vol. 26, no. 8. October 1984.

38. Organization for Economic Cooperation and Development. Environmental Effects of Electricity Generation. Paris: Organization for Economic Cooperation and Development. August, 1984, p. 121.

39. Ibid, pp. 110-113, p. 120.

40. Ibid, pp. 122-123.

41. Ibid, pp. 114-116.

42. U.S. Department of Energy. Technology Characterizations: Environmental Information Handbook, DOE/EP-0028. June, 1981, p. 5, 12, 27.

43. U.S. Department of Energy, San Francisco Operations Office. Final Programmatic Environmental Assessment of the U.S. Department of Energy's Photovoltaic Power Program. August 1980, p. 5-72 to 5-76.

44. "Cool Water: Milestone for Clean Coal Technology." EPRI Joumal. vol. 9, number 10, December 1984.

45. U.S. Department of Energy. Technology Characterizations: Environmental Information Handbook, DOE/EP-0028. June, 1981, p. 26, 30.

46. Ibid, appendix p. 33.

47. Organization for Economic Cooperation and Development. Emvironmental Effects of Electricity Generation. Paris: Organization for Economic Cooperation and Development. August, 1984, pp. 123-124.

48. U.S. Department of Energy, Energy Information Administration. Deterninants of Capital Casts for Coal-Fured Power Plants. October 1985, p. 32. 